\title{
Quercetin Inhibits ROS-p53-Bax-caspase-3 Axis of Apoptosis and Augments Gonadotropin and Testicular Hormones in Chronic Unpredictable Stress-Induced Testis Injury
}

\author{
La Quercetina Inhibe el Eje de Apoptosis ROS-p53-Bax-Caspasa-3 y Aumenta la Gonadotropina \\ y las Hormonas Testiculares en la Lesión Testicular Inducida por Estrés Crónico e Impredecible
}

Ismaeel Bin-Jaliah

BIN-JALIAH, I. Quercetin inhibits ROS-p53-bax-caspase-3 axis of apoptosis and augments gonadotropin and testicular hormones in chronic unpredictable stress-induced testis injury. Int. J. Morphol., 39(3):839-847, 2021.

SUMMARY: A large body of evidence supports the protective role of the flavonol antioxidant compound quercetin in mammals. We tested the hypothesis that quercetin can protect against the hypothalamus-pituitary-gonadal (HPG) axis defect like a reduction in gonadotropins and testicular hormones and abnormal semen analysis induced by chronic unpredictable stress (CUS), possibly via the downregulation of oxidative stress (ROS) and p53-Bax-caspase-3 pathways. Rats were either exposed to a variety of unpredictable stressors daily before being sacrificed after 3 weeks (model group) or were treated with quercetin (50 mg/kg body weight/day) at the same time the CUS were induced (treated group). Harvested testicular tissues were stained with basic histological staining, and testis homogenates were assayed for the tumor suppressor p53, apoptosis regulator Bax, B-cell lymphoma 2 (Bcl-2), caspase-3, malondialdehyde (MDA), glutathione peroxidase (GPx), and superoxide dismutase (SOD). In addition, harvested epididymis tissues were used to assess semen analysis, and blood samples were assayed for the testicular hormone testosterone, the adrenal cortex hormone corticosterone, and the anterior pituitary gonadotropins, follicular stimulating hormone (FSH) and luteinizing hormone (LH). CUS induced profound testicular damage and significantly $(\mathrm{p}<0.05)$ induced p53, Bax, caspase-3, MDA, and corticosterone, which were significantly $(\mathrm{p}<0.05)$ inhibited by quercetin except corticosterone. Whereas, quercetin significantly $(\mathrm{p}<0.05)$ increased FSH, LH, testosterone, Bcl-2, GPx, and SOD levels that were inhibited by CUS. In addition, CUS induced oligozoospermia, asthenozoospermia, and teratozoospermia, which were significantly $(\mathrm{p}<0.05)$ protected by quercetin. Thus, Quercetin protects against CUS-induced HPG defects in rats, which is associated with the inhibition of ROS-p53-Bax-caspase-3 axis.

KEY WORDS: Chronic stress; HPG Axis; Apoptosis; Testicles; Quercetin; Rat model.

\section{INTRODUCTION}

A prolonged exposure to one repetitive or multiple stressors leads to chronic stress that can undermine the mental and physical health of people by negatively affecting many organs and systems such as the reproductive, endocrine, cardiovascular, and central nervous systems (Clarke et al., 1999; Helmreich et al., 2005; Carnevali et al., 2012). Indeed, chronic stress caused cardiac arrest and death in more than a quarter of the mice that had their anti-stress receptor, serotonin knocked out (Carnevali et al.). In response to stress, the body mobilizes physiological and/or psychological resources to cope with these demands leading to alterations in the dynamic regulations of the autonomic, neuroendocrine, and immune systems (Pike et al., 1997). Accumulated evidence shows that chronic stress such as those arising from natural disasters, wars, economic deprivation or induced by experimental procedures, is a risk factor for male infertility and reproductive dysfunction in both humans and animals (Clarke et al.; Prasad et al., 2012). For example, exposure to various forms of psychological or occupational stressors resulted in suppression of the hypothalamic-pituitarygonadal (HPG) axis, which negatively affected the quantity and quality of sperm production (Othman et al., 2016).

The mechanisms responsible for stress-related testicular damage and alterations in semen quality have not been fully elucidated. However, tissue oxidative stress is 
believed to be the main cause behind damage which occurs in animals and humans exposed to traumatic events including chronic stress (de Farias et al., 2013; Mitra et al., 2013). Stress-induced overproduction of reactive oxygen species (ROS) caused apoptosis and enhanced levels of lipid peroxidation and peroxynitrite that damages DNA in the brain and testes (Matsumoto et al., 1999; Hamilton et al., 2018). In addition, higher levels of ROS, lower levels of testicular antioxidant enzymes and a decrease in sperm viability, motility and fertility rate were seen in rats following forced swimming exercise stress (Minaii et al., 2014).

Quercetin is a flavonol antioxidant and antiinflammatory compound that is found in many vegetables, fruits, and grains (Nishimuro et al., 2015; Xu et al., 2019). Quercetin has many pleotropic effects that demonstrated effective protection to the cardiovascular, kidney, and liver (Chen et al., 2013; Zhang et al., 2017; Yang et al., 2018), and preventing apoptosis and promoting cell survival (Choi et al., 2005). In addition, quercetin inhibited cadmiuminduced oxidative stress and testicular damage (Kanter et al., 2016). However, the potential inhibition of the p53-Baxcaspase- 3 apoptotic pathways and the damage to HPG axis by quercetin in CUS-induced testicular injury in rats is unknown. Therefore, we speculated that activation of p53Bax-caspase- 3 axis and inhibition of HPG axis by CUS in a rat model of testicular injury could be inhibited with quercetin.

\section{MATERIAL AND METHOD}

Animals. All animal experiments were performed according to the Guide for the Care and Use of Laboratory Animals published by the US National Institutes of Health (NIH publication No.85-23, revised 1996), and with the approval by the Medical Research Ethical Committee at King Khalid University, Abha, Saudi Arabia (Ref no: REC. NO. 201406-09). Male Wistar rats (total 24 rats) at 8 weeks and weighing 150-200 g were used for these studies. They had free access to food and water and were housed under a constant temperature of $23 \pm 1{ }^{\circ} \mathrm{C}$ with a 12-hour light/ dark cycle.

Experimental design. After a one-week adaptation period, rats were randomly assigned into 4 groups $(n=6$ each) as follows: 1. Control group: received normal saline. 2 . Quercetin treated group (QUR): rats received QUR (50 mg/ $\mathrm{kg}$ ) (Anjaneyulu et al., 2003). 3. Chronic unpredictable stress (CUS) group: a model group and were exposed to CUS protocol, as detailed below and received normal saline. 4 . CUS + QUR treated group: were exposed to CUS with a concomitant daily dose of QUR $(50 \mathrm{mg} / \mathrm{kg})$. All treatments were administered as $1 \mathrm{ml}$, i.p. for three consecutive weeks on a daily basis.

Chronic unpredictable stress (CUS) protocol. CUS protocol was induced as previously described (Harro et al., 1999) with modification. Briefly, a set of chronic unpredictable stressors were used to induce depression in rats that lasted for 3 weeks.

Preparation of blood samples and testicular tissues for analysis. At the end of the experimental period, blood samples were collected by cardiac puncture under anesthesia (sodium thiopental at $40 \mathrm{mg} / \mathrm{kg}$ body weight) for hormonal assay, and rats were then sacrificed by cervical dislocation. Testicular tissues were collected and washed with iced phosphate buffered saline (PBS). Parts of the testes were homogenized with an ultrasonic homogenizer in a cold phosphate buffer, pH 7.4, containing EDTA. The supernatant obtained was distributed in separate tubes and stored at $80^{\circ} \mathrm{C}$ for biochemical analysis. Other parts of the testes were stored at $-80^{\circ} \mathrm{C}$ for RNA extraction.

Histological study. Testis specimens were dissected and immediately fixed in a $10 \%$ formol saline for 24 hours. Paraffin blocks were processed, sectioned in $5 \mathrm{~mm}$ thickness and subjected to hematoxylin and eosin (H\&E) staining to observe the morphological changes.

Determination of serum levels of $\mathrm{FSH}, \mathrm{LH}$, testosterone, and corticosterone. Serum levels of FSH (Cat. No. ab108641, Cambridge, UK), LH (Cat. No. CSB-E12654r, Cusabio Biotech Co., Ltd., China), and testosterone (Cat. No. E0930Ra, Shanghai Crystal Day Biotech Co., Ltd. China) were measured according to the manufacturer's instructions using ELISA kits. Serum corticosterone was determined using commercial kit supplied by IBL, USA, according to the manufacturer's instructions.

Determination of tissue levels of oxidative stress and antioxidants, inflammation, and apoptosis and survival biomarkers. Prepared testis tissue homogenates were used to determine tissue levels of malondialdehyde (MDA) (Cat No. NWK-MDA01, NWLSS, USA), superoxide dismutase (SOD) (Cat.No. 706002, Cayman Chemical, Ann Arbor, MI, USA), glutathione peroxidase (GPx) (Cat.No. 703102, Cayman Chemical, Ann Arbor, MI, USA), interleukin 6 (IL-6) (Cat No. ELR-IL6-001) RayBio, MO, USA), tumor necrosis factor alpha (TNF- $\alpha$ ) (Cat no. ab46070, Abcam, Cambridge, MA, USA), caspase 3 (Cat. No. R5814), and Bcl-2 (Cat. No. R6813, STZ ELISA, USA). They were measured according to the manufacturers' instructions. 
Detection of p53 and Bax messenger RNAs by reverse transcriptase-polymerase chain reaction. As recently described by Al Humayed et al. (2020), total RNAs were isolated from freshly dissected rats' testes using the RNeasy Mini Kit (Qiagen Pty, Victoria, Australia). The RNA was reverse-transcribed for a single strand cDNA synthesis (Invitrogen) and amplified by PCR for p53, Bax, and b-actin. The PCR products were separated by $2 \%$ agarose gel electrophoresis and visualised by ethidium bromide. Gel images were scanned and quantified by densitometry using the NIH image software.

Semen analysis. Right cauda epididymis from each rat was minced and diluted with 1:20 normal saline. The total number of sperm in the 5 small central squares of a glass hemocytometer was counted under a light microscope (400x) with a volume correction of 50. Counting was done in triplicates and the count was first expressed per milliliter and then converted to per $0.1 \mathrm{~g}$ weight. Also, motile and immotile sperm were counted in a total of 300 sperm samples, and the results were expressed as percentages of total count. In another set of experiments, an expert in sperm morphology, working blind, visualized sperm suspended in one drop of eosin under a light microscope for the assessment of sperm morphology. The following morphological features were assessed: Absence of head, absence of tail, tail bending and tail coiling. All samples were analyzed in triplicate and mean readings \pm SD were presented for each rat.

Statistical analysis. Statistical analysis was performed by using the Graphpad prism statistical software package (version 6). The data were expressed as mean \pm standard deviation (SD). Normality and homogeneity of the data were confirmed before ANOVA). One-way analysis of variance (ANOVA) was performed followed by Tukey's t test.

\section{RESULTS}

Quercetin inhibits CUS-induced defects to the HPG axis but not HPA axis. Chronic stress is a well-known inhibitor of HPG and inducer of hypothalamus-pituitary-adrenal (HPA) axes (Kanter et al.). To test the hypothesis that
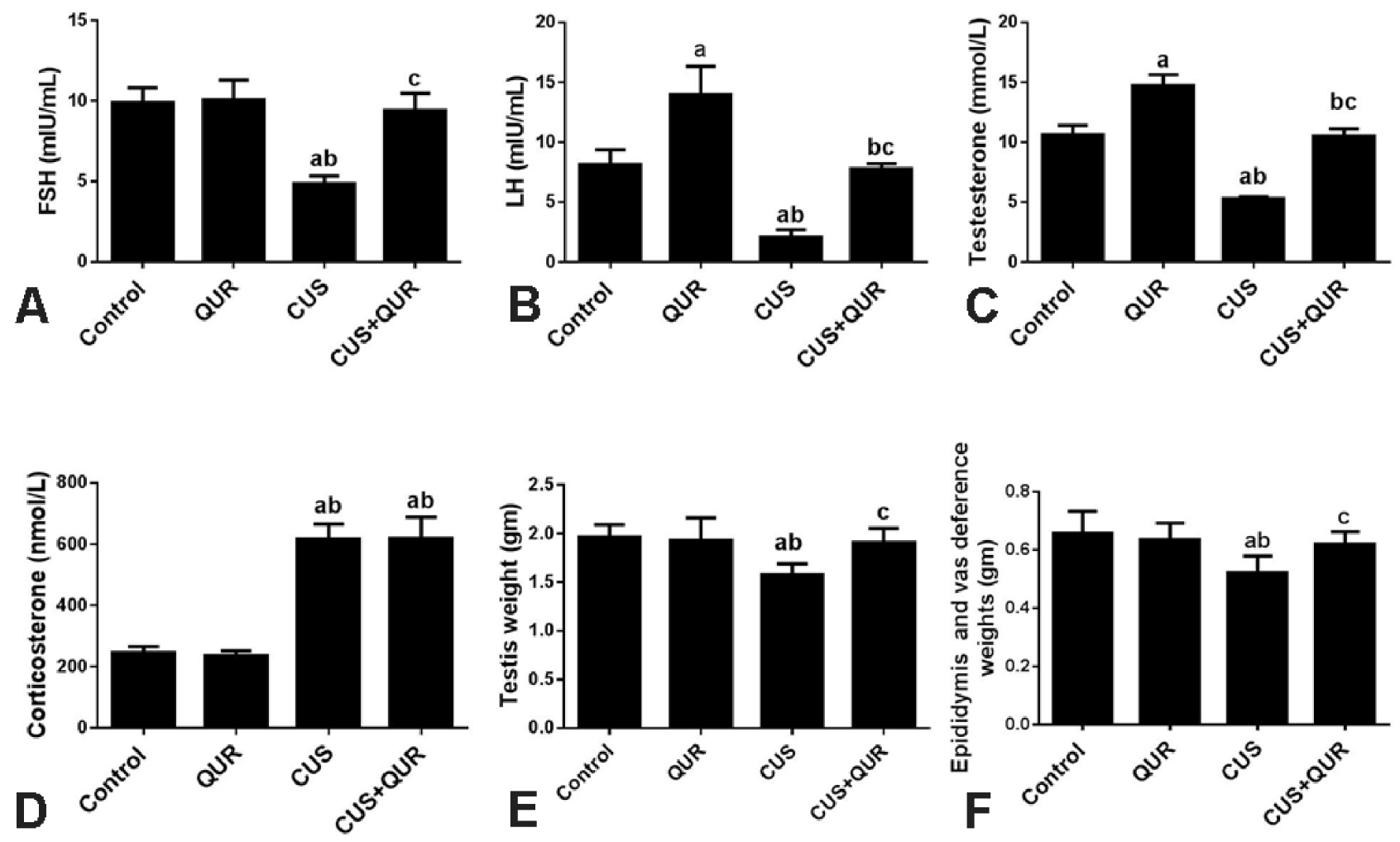

Fig. 1. Quercetin increases circulating levels of HPA axis hormones inhibited by CUS and protects the reduction in testis weight. Blood levels of FSH (A), LH (B), testosterone (C), and corticosterone (D) hormones, and testis weight (E) and epididymis plus vas deferens weight (Fig. 1F) were measured at the end of the experiment in all groups of rats; Control, QUR, CUS, and CUS+QUR groups. Results represent the mean $( \pm S D) ; n=6$ for each group. All shown $p$ values are significant. a: Significant in comparison to control; b:Significant in comparison to QUR; c:Significant in comparison to CUS. CUS: chronic uncontrolled stress; QUR: quercetin; FSH: follicular stimulating hormone; LH: luteinizing hormone. 
quercetin in our modified model of CUS can protect against CUS-modulated HPG and HPA axes defects, we measured blood levels of FSH, LH, testosterone, and corticosterone hormones in all groups of rats. Compared with the control and QUR groups, CUS significantly $(\mathrm{p}<0.5)$ ameliorated FSH (Fig. 1A), LH (Fig. 1B), testosterone (Fig. 1C), and augmented corticosterone (Fig. 1D), which were significantly $(\mathrm{p}<0.5)$ protected by quercetin $(\mathrm{CUS}+\mathrm{QUR})$ to levels comparable to the control group (Fig. 1A-1C) with the exception of corticosterone that showed no effects (Fig. 1D). In addition, CUS caused a significant $(\mathrm{p}<0.05)$ decrease in testes weight (Fig. 1E) and epididymis plus vas deferens weight $($ Fig. $1 \mathrm{~F})$ that were significantly $(\mathrm{p}<0.5)$ protected by quercetin (CUS+QUR) to levels comparable to control groups.

Quercetin inhibits CUS-induced abnormal semen analysis. To investigate whether the observed protection to HPG axis, testes weight, and epididymis plus vas deferens weights in the treated group of rats (CUS+QUR) shown above was also associated with restoration of normal semen analysis, we determined sperm count, sperm motility, and sperm morphology in the quercetin-treated group (CUS+QUR) and compared it to the model group (CUS) and control groups, 21 days after the beginning of the CUS protocol (Table I). Quercetin treatment significantly $(\mathrm{p}<0.05)$ inhibits CUS-induced oligozoospermia, asthenozoospermia, and teratozoospermia. However, the degree of protection exerted by quercetin was partial in sperm count, absence of sperm tail, and absence of sperm head (Table I).

Quercetin and CUS modulate oxidative stress and antioxidants testis levels but not biomarkers of inflammation. Tissue oxidative stress is known to be involved in the pathogenesis of testicular injury (Zhao et al., 2011). To determine whether quercetin in our modified model of CUS can protect against testicular injury caused by CUS, we measured MDA as a by-product of lipid peroxidation, the antioxidants SOD and GPx, and the inflammatory biomarkers IL-6 and TNF- $\alpha$ using ELISA method in testis tissue homogenates of all groups of rats. Compared with the control and QUR groups, CUS significantly ( $\mathrm{p}<0.5)$ augmented MDA (Fig. 2A), and ameliorated SOD (Fig. 2B) and GPx (Fig. 2C) tissue levels, which were significantly $(\mathrm{p}<0.5)$ protected by quercetin (CUS+QUR) to levels comparable to the control group. However, neither CUS nor QUR changed the levels of TNFa (Fig. 2D) and IL-6 (Fig. 2E).

Quercetin protects CUS-modulated the apoptosis and survival biomarkers in testis tissues. We then tested the p53-Bax-caspase-3 axis cell signalling in testis tissue since this apoptotic pathway is located downstream of the oxidative stress in the cell signalling pathways (Gambino et al., 2013). CUS strongly (i) augmented p53 and Bax cDNA message (Fig. 3A-3C); (ii) augmented caspase-3 protein expression (Fig. 3D); and (iii) inhibited the survival protein Bcl-2 (Fig. $3 \mathrm{E})$, which were effectively protected by quercetin to levels comparable to the control group, but still significant to the control group in (B).

Quercetin protects against CUS-induced testicular tissue damage. Chronic stress is well-known to induce testicular damage (Allen et al., 2004). To determine whether the flavonoid antioxidant compound quercetin can protect against chronic stress-induced pathological changes in the testis, harvested testicular tissues from all animal groups were stained with H\& E and examined under light microscopy. Compared to a normal tissue structure in the control group (Fig. 4A) showing the seminiferous tubules containing the spermatogenic lineage such as spermatogonia (S), primary spermatocytes (S1), spermatids (S3), and spermatozoa (S4). In addition, the sustentacular cells (Sertoli cells) (St) surrounded by myoid cells $(\mathrm{M})$, and the spaces between the

Table I. Quercetin protects against CUS-induced abnormal semen analysis in rats. Sperm count and motility, and abnormal sperm shapes were obtained at the end of the experiment in all animal groups. Values are expressed as Mean \pm SD for 6 rats in each group. Values were considered significantly different at $\mathrm{P}<0.05$. a: Significant in comparison to control;b:Significant in comparison to QUR; c:Significant in comparison to CUS.

\begin{tabular}{lcccccc}
\hline Animal Groups & $\begin{array}{c}\text { Sperm count } \\
\left(\times 10^{6 / 0.1 \mathrm{gm}}\right. \\
\text { epididymis })\end{array}$ & $\begin{array}{c}\text { S perm motility } \\
(\%)\end{array}$ & $\begin{array}{c}\text { Absence of } \\
(\%)\end{array}$ & $\begin{array}{c}\text { Absence of tail } \\
(\%)\end{array}$ & $\begin{array}{c}\text { Tail bending } \\
(\%)\end{array}$ & $\begin{array}{c}\text { Tail coiling } \\
(\%)\end{array}$ \\
\hline Control & 91.00 & 61.17 & 2.75 & 0.726 & 3.167 & 4.150 \\
& \pm 4.427 & \pm 4.535 & $0.609 \pm$ & $0.523 \pm$ & $0.5046 \pm$ & $0.524 \pm$ \\
QUR & 121.7 & 80.33 & 2.88 & 0.710 & 2.917 & 4.033 \\
& $\pm 6.408^{\mathrm{a}}$ & $\pm 6.250^{\mathrm{a}}$ & $0.591 \pm$ & $0.510 \pm$ & $0.5707 \pm$ & $0.500 \pm$ \\
CUS & 31.17 & 20.83 & 15.33 & 7.583 & 6.683 & 19.00 \\
& $\pm 5.707^{\mathrm{ab}}$ & $\pm 4.535 \mathrm{ab}$ & $\pm 3.78^{\mathrm{ab}}$ & $\pm 1.563^{\mathrm{ab}}$ & $\pm 0.649^{\mathrm{ab}}$ & $\pm 4.733^{\mathrm{ab}}$ \\
CUS+QUR & 62.00 & 60.67 & 4.45 & 3.800 & 3.300 & 6.850 \\
& $\pm 5.44^{\mathrm{abc}}$ & $\pm 4.03 \mathrm{~b}^{\mathrm{c}}$ & $\pm 1.11 \mathrm{a}^{\mathrm{bc}}$ & $\pm 0.672^{\mathrm{abc}}$ & $\pm 0.596^{\mathrm{c}}$ & $\pm 1.127^{\mathrm{c}}$ \\
\hline
\end{tabular}

Abbreviations: CUS, chronic unpredictable stress; QUR, quercetin. 

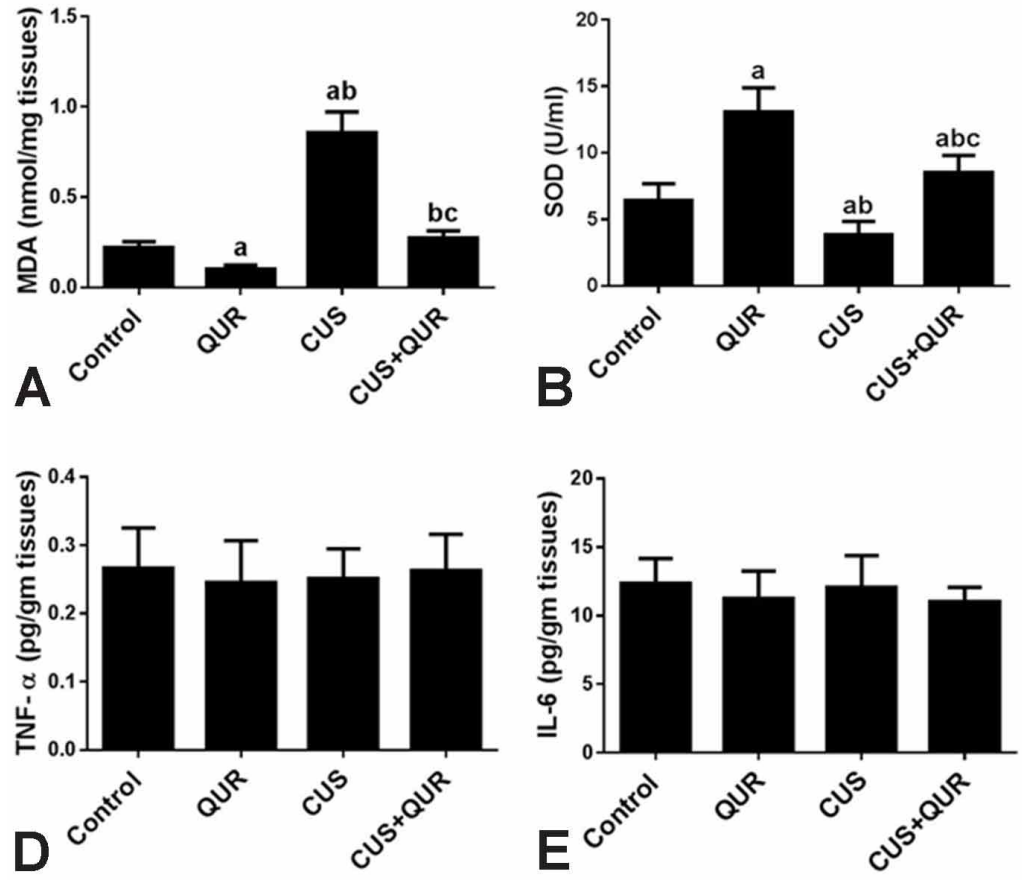

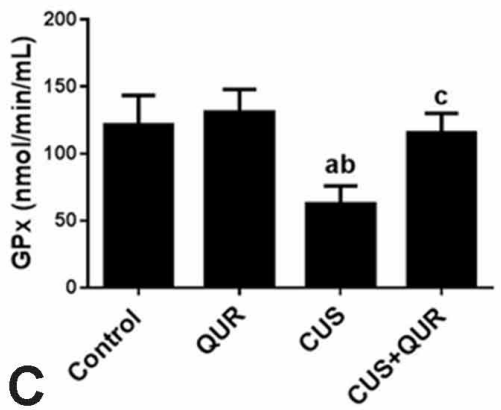

Fig. 2. CUS and Quercetin modulate biomarkers of oxidative stress but not inflammatory biomarkers. Testis tissue levels of MDA (A), SOD (B), GPx (C), TNF- $\alpha$ (D), and IL-6 (E) were measured at the end of the experiment in all groups of rats; Control, QUR, CUS, and CUS+QUR groups. Results represent the mean $( \pm S D) ; n=6$ for each group. All shown $p$ values are significant. ${ }^{\text {a: }}$ Significant in comparison to control; ': Significant in comparison to QUR; c:Significant in comparison to CUS. CUS: chronic uncontrolled stress; QUR: quercetin; MDA: malondialdehyde; SOD: superoxide dismutase; GPx: glutathione peroxidase TNF$\alpha$ : tumor necrosis factor alpha; IL-6: interleukin 6.

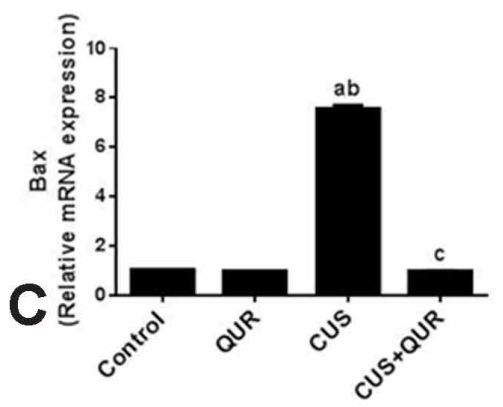

Fig. 3. Quercetin inhibits CUS-induced p53Bax-caspase- 3 axis. Testis tissue levels of p53 and $\mathrm{Bax}$ gene expression were measured using RT-PCR analysis (A - C), and caspase-3 (D) and Bcl-2 (E) protein expression measured by ELISA at the end of the experiment in all groups of rats; Control, QUR, CUS, and CUS+QUR groups. For (A): lane 1 = control; lane $2=\mathrm{QUR}$; lane 3 = CUS; and lane $4=$ CUS+QUR groups. Results represent the mean $( \pm \mathrm{SD}) ; \mathrm{n}=6$ for each group. All shown p values are significant. ${ }^{\mathrm{a}}$ : Significant in comparison to control; b:Significant in comparison to QUR; : :Significant in comparison to CUS. CUS: chronic uncontrolled stress; QUR: quercetin; p53: tumor suppressor p53; Bax: apoptosis regulator Bax; Bcl-2: B-cell lymphoma 2. 
tubules contain connective tissue and interstitial cells (Leydig cells) (L) can be seen. Whereas, representative H\&E stained sections of testicular tissues from the model group (CUS) showed (Fig. 4B and 4D) evidence of substantial tissue damage as demonstrated by disrupted sustentacular cells, vacuolated spermatogenic lineage with atrophic nuclei, and loss of sperms in the lumen of the seminiferous tubules, which that significantly protected by quercetin (Fig. 4C and 4D).We further reinforced the link between testicular injury and oxidative stress and apoptosis by measuring correlation between the score of testicular injury and the tissue levels of MDA (Fig. 4E) and p53 (Fig. 4F). Testicular injury grade score displayed positive correlation with MDA $(r=0.954$; $\mathrm{p}<0.0001)$, and $\mathrm{p} 53(\mathrm{r}=0.974 ; \mathrm{p}<0.0001)$.
Correlation between p53 or testosterone and sperm count, LH, and antiapoptotic protein. The correlation between either $\mathrm{p} 53$ or testosterone scorning and sperm count and blood and tissue levels of $\mathrm{LH}$ and Bcl-2 were determined in order to further confirm and characterize the role of QUR as being stable and an appropriate agent in testis injury rats, and to further support the link between these parameters in animal model of CUS-induced testis injury. A significant $(p<0.0001)$ correlation was observed between $\mathrm{p} 53$ and $\mathrm{LH}$ $(\mathrm{r}=-955$; Fig. 5A), $\mathrm{p} 53$ and testosterone $(\mathrm{r}=-968$; Fig. 5B), p53 and sperm count $(r=-927$; Fig. 5C), testosterone and Bcl-2 $(r=967$; Fig. 5D), testosterone and $\mathrm{LH}(\mathrm{r}=927$; Fig. 5E), and testosterone and sperm count $(\mathrm{r}=862$; Fig. $5 \mathrm{~F})$.
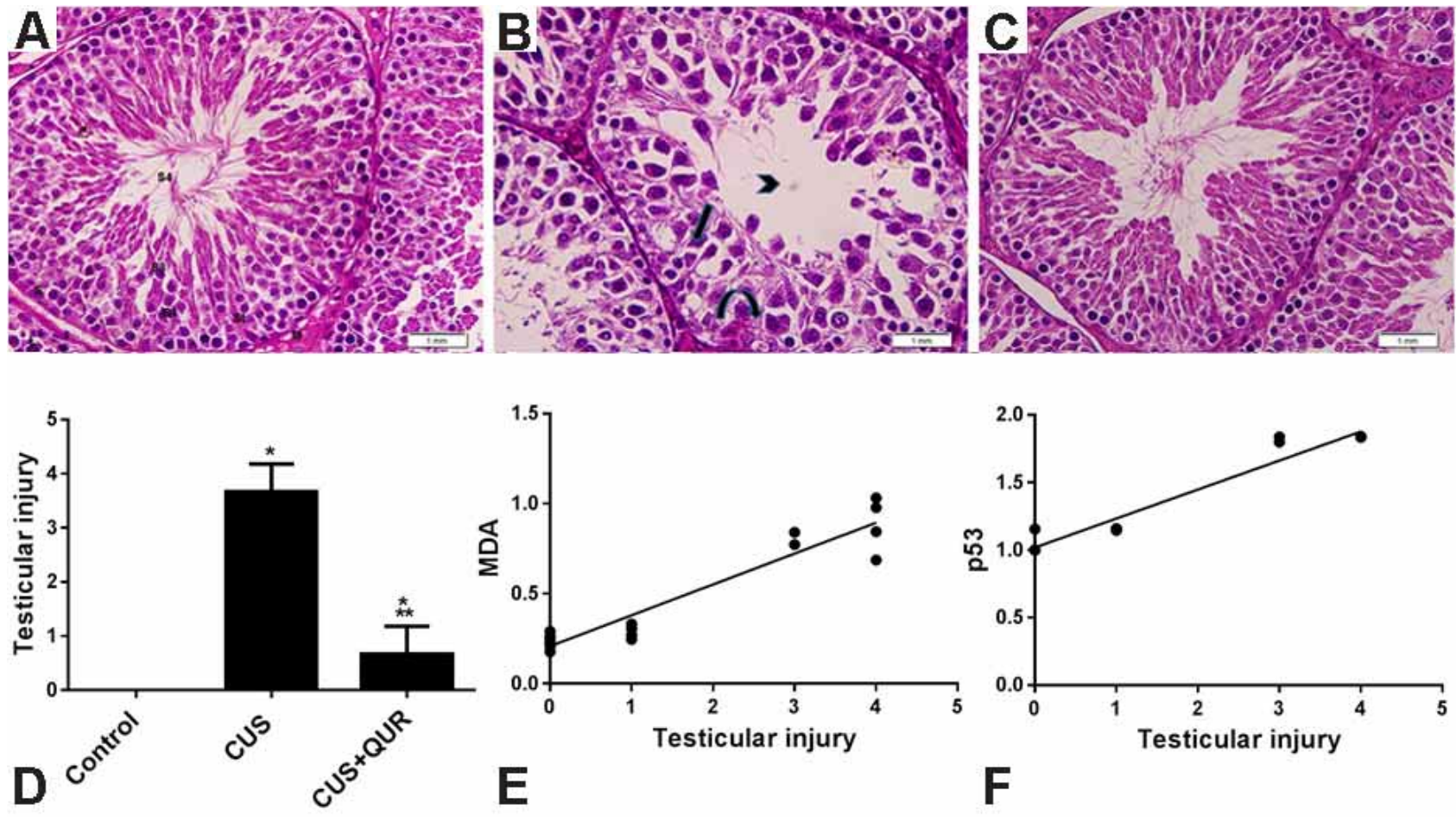

Fig. 4. Quercetin protects the architecture of testis tissue against injury induced by CUS. H\&E stained images (400x) of harvested tissues obtained after 3 weeks from the testesof the control group (A), the model group, CUS (B) and treated group, CUS+QUR (C) are visualized using light microscopy. Note that in B, arrow points to disrupted spermatogenic lineage cell, curved arrow points to disrupted sustentacular cells (Sertoli cells), and arrowhead points to the luminal seminiferous tubules compartment. CUS: chronic uncontrolled stress; QUR: quercetin; MDA: malondialdehyde; p53: tumor suppressor p53.

\section{DISCUSSION}

This article examines the development of testicular injury secondary to CUS in a rat model of the disease using molecular, biochemical, and basic histology approaches that show effective protection by quercetin. In addition, this study links CUS with the pathophysiology of HPG and HPA axes that involved oxidative stress and apoptosis cell signaling in testicular tissues. These conclusions are supported by the data indicating that exposure of rats to CUS for 3 weeks led to defects in both HPG (Figs, 1A-1C) and HPA (Fig. 1D) axes; decreased gonad weight (Figs. 1E and 1F); abnormal semen analysis (Table I); oxidative stress (Figure 2A-2C); activation of p53-Bax-caspase-3 axis (Figs. 3A-3D); 

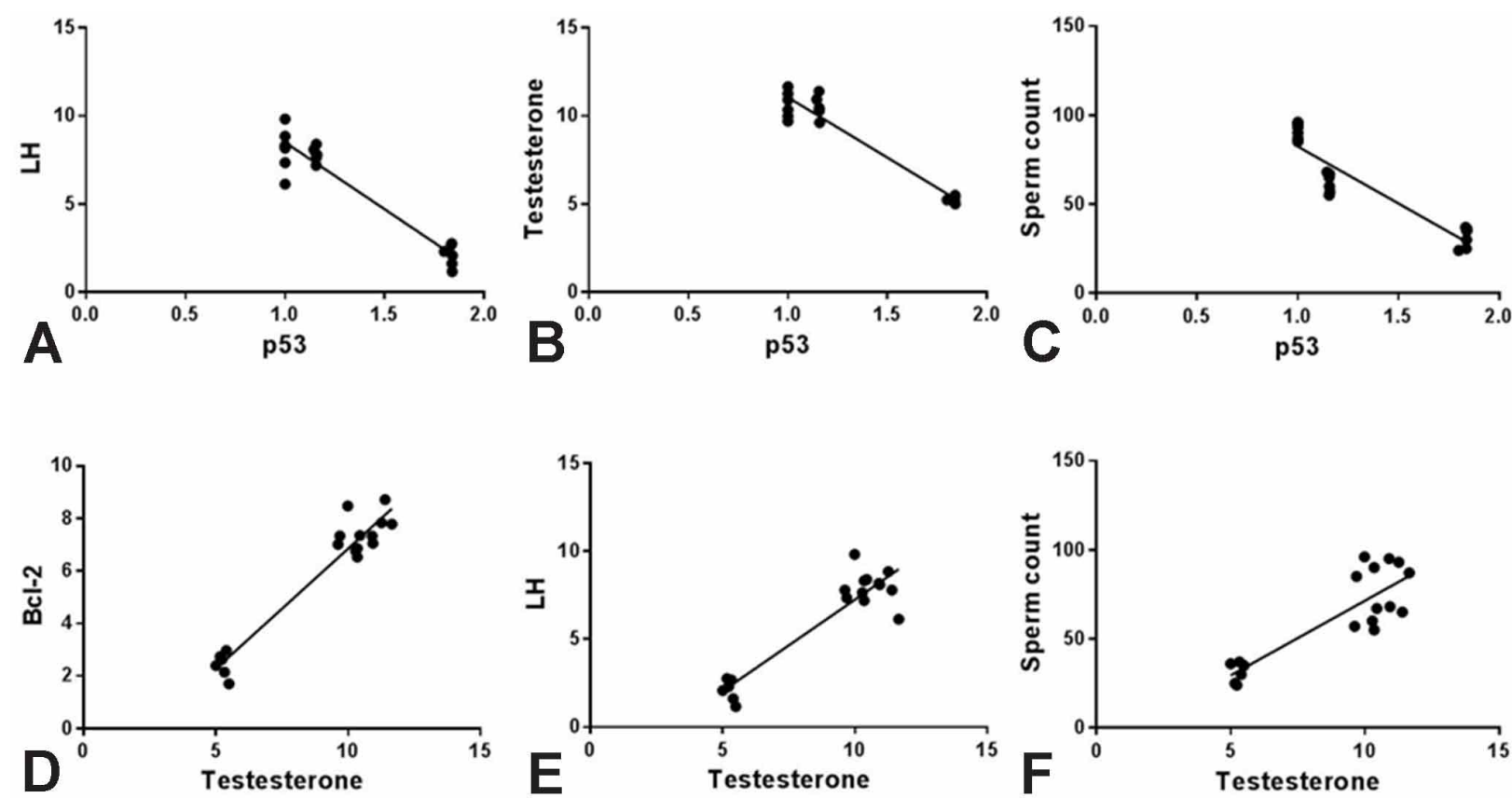

Fig. 5. Correlation between p53 or testosterone and markers of semen analysis and oxidative stress. P53 and testosterone levels were measured in all groups of rats and the correlation between p53 and LH, p53 and testosterone, and p53 and sperm count are shown in (A, $\mathrm{B}, \mathrm{C})$, respectively. The correlation between testosterone and $\mathrm{Bcl}-2$, testosterone and $\mathrm{LH}$, and testosterone and sperm count are shown in (D, E, F), respectively.p53: tumor suppressor p53; LH: luteinizing hormone; Bcl-2: B-cell lymphoma 2.

inhibition of survival biomarker, Bcl-2 (Fig. 3E); and testicular injury, which were substantially protected by quercetin (Figs. 1-4 and Table I), with the exception of corticosterone levels (Fig. 1D). Also, our data that shows a significant positive correlation between testicular injury and oxidative stress and apoptosis, and negative correlation between apoptosis and testosterone and sperm count support our conclusions mentioned above.

The testis is a known target affected by acute and chronic stress (Hansen, 2009; Ren et al., 2010; Nordkap et al., 2016), and our data (Figs. 1-4) confirms the development of testicular injuries as one of the CUS complications occurring 3 weeks after the start of the CUS protocol in rats, are in agreement with several studies which show that both types of stress, acute and chronic induced several pathological manifestation of testicular injuries in animal models and humans (Ren et al.; Nargund, 2015; Ribeiro et al., 2018). For example, adult male rats exposed to acute restraint stress caused (a) reduction in plasma LH, FSH, and testosterone; (b) elevation of plasma adrenocorticotropic hormone (ACTH) and corticosterone; and (c) changes in epididymal sperm motility parameters (Ren et al.). Furthermore, inhibition of the HPG axis leads to a decrease in testosterone levels, which causes changes in sustentacular cells and the blood-testis barrier, leading to the arrest of spermatogenesis (Nargund). However, little is known about the effects of psychological stress on human testes (Clarke et al.; Nordkap et al.) and most of the data comes from animal models. Therefore, it is recommended that patients should be made aware of the adverse effects of psychological stress on testicular function and fertility (Nargund).

Our data which points to the beneficial effects of the antioxidant quercetin on CUS-induced testicular injury associated with the inhibition of oxidative stress and augmentation of testosterone in rats are in agreement with previous studies (Kanter et al.; Avdatek et al., 2018; Samad et al., 2018). These studies reported (i) an inhibition of testicular oxidative stress and improvement of sperm motility by the antioxidant resveratrol (Avdatek et al.); (ii) quercetin inhibited cadmium-induced oxidative stress and testicular damage (Kanter et al.); and (iii) quercetin pre-treatment protects against stress-induced anxiety and depression-like behavior and improves memory in male mice (Samad et al.).

In cell signalling, oxidative and nitrosative stress is located upstream of the apoptotic biomarkers upon activation in many cases such as brain and vascular injury (Cenini $e t$ al., 2008; Gambino et al.; Liang \& Su, 2019). Oxidative stress and activation of $\mathrm{p} 53$ were reported to be involved in diabetes-induced testicular apoptosis (Zhao et al.). In 
addition, deletion of p53 and the redox that generates mitochondrial ROS by genetic means reduced apoptosis and increased longevity of transgenic mice (Gambino et al.). Furthermore, Benzo (a) pyrene induced oxidative stress and apoptotic proteins $\mathrm{p} 53$ and Bax in isolated testicular germ cells, which were ameliorated with curcumin and resveratrol (Banerjee et al., 2016). These reports are in agreement with our data that demonstrate the association between CUSinduced testicular injury and apoptosis and oxidative stress. Also, our data shown here are in agreement with our recently published report that showed modulation of these parameters; p53, Bax, Bcl-2, and biomarkers of oxidative stress in acute liver injury (Al Humayed et al.).

To conclude, we have demonstrated that induction of CUS for 3 weeks in rats induced testicular injury via the inhibition of HPG axis associated with the induction of oxidative stress and apoptosis, which were protected by quercetin.

\section{ACKNOWLEDGMENTS}

The author highly appreciates the support and input of Professors Bahjat Al-Ani, Mohamed A Haidara and Mohamed Samir Zaki from the College of Medicine, King Khalid University, Abha, Saudi Arabia. Thanks are due to Dr Mariam Al-Ani for proofreading the manuscript.

BIN-JALIAH, I. La quercetina inhibe el eje de apoptosis ROSp53-Bax-caspasa-3 y aumenta la gonadotropina y las hormonas testiculares en la lesión testicular inducida por estrés crónico e impredecible. Int. J. Morphol., 39(3):839-847, 2021.

RESUMEN: El papel protector del compuesto antioxidante flavonol quercetina en los mamíferos ha sido ampliamente reportado. Probamos la hipótesis que la quercetina puede proteger contra el defecto del eje hipotálamo-hipofisiariogonadal (HHG) como una reducción de gonadotropinas y hormonas testiculares y análisis de semen anormal inducido por estrés crónico impredecible (ECI), posiblemente a través de la regulación reducida del estrés oxidativo (REO) y las vías p53Bax-caspasa-3. Las ratas fueron expuestas a una variedad de factores estresantes impredecibles diariamente antes de ser sacrificadas después de 3 semanas (grupo modelo) o fueron tratadas con quercetina (50 mg / kg de peso corporal / día) al mismo tiempo que se indujo la ECI (grupo tratado). Los tejidos testiculares fueron teñidos con tinción histológica básica y los homogeneizados de testículo se analizaron para determinar el supresor de tumores p53, el regulador de apoptosis Bax, el linfoma de células B 2 (Bcl-2), la caspasa-3, el malondialdehído (MDA), la glutatión peroxidasa (GPx) y superóxido dismutasa (SOD). Además, se utilizaron tejidos del epidídimo recolecta- dos para evaluar el análisis de semen y se analizaron muestras de sangre para determinar la hormona testicular testosterona, la hormona corticosterona de la corteza suprarrenal y las gonadotropinas de la hipófisis anterior, la hormona estimulante folicular (FSH) y la hormona luteinizante (LH). El ECI indujo daño testicular importante e indujo significativamente niveles de (p <0,05) p53, Bax, caspasa-3, MDA y corticosterona, que fueron inhibidos $(p<0,05)$ por la quercetina. La quercetina aumentó significativamente $(\mathrm{p}<0,05)$ los niveles de FSH, LH, testosterona, Bcl-2, GPx y SOD que fueron inhibidos por ECI. Además, ECI indujo oligozoospermia, astenozoospermia y teratozoospermia, protegidos de manera significativa $(\mathrm{p}<0,05)$ por la quercetina. Por lo tanto, la quercetina protege contra los defectos de HHG inducidos por ECI en ratas, lo que está asociado con la inhibición del eje ROS-p53-Bax-caspasa-3.

PALABRAS CLAVE: Estrés crónico; Eje HPG; Apoptosis; Testículos; Quercetina; Modelo de rata.

\section{REFERENCES}

Al Humayed, S.; Al-Hashem, F.; Haidara, M. A.; El Karib, A. O.; Kamar, S. S.; Amin, S. N. \& Al-Ani, B. Resveratrol pretreatment ameliorates p53-Bax axis and augments the survival biomarker B-cell lymphoma 2 modulated by paracetamol overdose in a rat model of acute liver injury. Pharmacology, 105(1-2):39-46, 2020.

Allen, J. A.; Diemer, T.; Janus, P.; Hales, K. H. \& Hales, D. B. Bacterial endotoxin lipopolysaccharide and reactive oxygen species inhibit Leydig cell steroidogenesis via perturbation of mitochondria. Endocrine, 25(3):265-75, 2004.

Anjaneyulu, M.; Chopra, K. \& Kaur, I. Antidepressant activity of quercetin, a bioflavonoid, in streptozotocin-induced diabetic mice. J. Med. Food, 6(4):391-5, 2003

Avdatek, F.; Birdane, Y. O.; Türkmen, R. \& Demirel, H. H. Ameliorative effect of resveratrol on testicular oxidative stress, spermatological parameters and DNA damage in glyphosate-based herbicide-exposed rats. Andrologia, 50(7):e13036, 2018

Banerjee, B.; Chakraborty, S.; Ghosh, D.; Raha, S.; Sen, P. C. \& Jana, K. Benzo(a)pyrene induced p53 mediated male germ cell apoptosis: synergistic protective effects of curcumin and resveratrol. Front. Pharmacol., 7:245, 2016.

Carnevali, L.; Mastorci, F.; Audero, E.; Graiani, G.; Rossi, S.; Macchi, E.; Callegari, S.; Bartolomucci, A.; Nalivaiko, E.; Quaini, F.; et al. Stress-induced susceptibility to sudden cardiac death in mice with altered serotonin homeostasis. PLoS One, 7(7):e41184, 2012.

Cenini, G.; Sultana, R.; Memo, M. \& Butterfield, D. A. Effects of oxidative and nitrosative stress in brain on $\mathrm{p} 53$ proapoptotic protein in amnestic mild cognitive impairment and Alzheimer disease. Free Radic. Biol. Med., 45(1):81-5, 2008.

Chen, Y. W.; Chou, H. C.; Lin, S. T.; Chen, Y. H.; Chang, Y. J.; Chen, L. \& Chan, H. L. Cardioprotective effects of quercetin in cardiomyocyte under ischemia/reperfusion injury. Evid. Based Complement. Alternat. Med., 2013:364519, 2013

Choi, Y. J.; Jeong, Y. J.; Lee, Y. J.; Kwon, H. M. \& Kang, Y. H. ()Epigallocatechin gallate and quercetin enhance survival signaling in response to oxidant-induced human endothelial apoptosis. J. Nutr., 135(4):707-13, 2005.

Clarke, R. N.; Klock, S. C.; Geoghegan, A. \& Travassos, D. E. Relationship between psychological stress and semen quality among in-vitro fertilization patients. Hum. Reprod., 14(3):753-8, 1999. 
de Farias, J. M.; Bom, K. F.; Tromm, C. B.; Luciano, T. F.; Marques, S. O.; Tuon, T.; Silva, L. A.; Lira, F. S.; de Souza, C. T. \& Pinho, R. A. Effect of physical training on the adipose tissue of diet-induced obesity mice: interaction between reactive oxygen species and lipolysis. Horm. Metab. Res., 45(3):190-6, 2013.

Gambino, V.; De Michele, G.; Venezia, O.; Migliaccio, P.; Dall'Olio, V.; Bernard, L.; Minardi, S. P.; Della Fazia, M. A.; Bartoli, D.; Servillo, G.; et al. Oxidative stress activates a specific p53 transcriptional response that regulates cellular senescence and aging. Aging Cell, 12(3):435-45, 2013.

Hamilton, T. R. D. S.; Siqueira, A. F. P.; de Castro, L. S.; Mendes, C. M.; Delgado, J. C.; de Assis, P. M.; Mesquita, L. P.; Maiorka, P. C.; Nichi, M.; Goissis, M. D.; et al. Effect of heat stress on sperm DNA: protamine assessment in ram spermatozoa and testicle. Oxid. Med. Cell. Longev., 2018:5413056, 2018.

Hansen, P. J. Effects of heat stress on mammalian reproduction. Philos. Trans. R. Soc. Lond. B Biol. Sci., 364(1534):3341-50, 2009.

Harro, J.; Häidkind, R.; Harro, M.; Modiri, A. R.; Gillberg, P. G.; Pähkla, R.; Matto, V. \& Oreland, L. Chronic mild unpredictable stress after noradrenergic denervation: attenuation of behavioural and biochemical effects of DSP-4 treatment. Eur. Neuropsychopharmacol., 10(1):5-16, 1999.

Helmreich, D. L.; Parfitt, D. B.; Lu, X. Y.; Akil, H. \& Watson, S. J. Relation between the hypothalamic-pituitary-thyroid (HPT) axis and the hypothalamic-pituitary-adrenal (HPA) axis during repeated stress. Neuroendocrinology, 81(3):183-92, 2005.

Kanter, M.; Aktoz, T.; Aktas, C.; Ozen, F.; Yarali, O. \& Kanter, B. Role of quercetin in cadmium-induced oxidative stress, testicular damage, and apoptosis in rats. Anal. Quant. Cytopathol. Histpathol., 38(1):45-51, 2016.

Liang, B. \& Su, J. Inducible Nitric Oxide Synthase (iNOS) mediates vascular endothelial cell apoptosis in Grass Carp Reovirus (GCRV)-induced hemorrhage. Int. J. Mol. Sci., 20(24):6335, 2019.

Matsumoto, K.; Yobimoto, K.; Huong, N. T.; Abdel-Fattah, M.; Van Hien, T. \& Watanabe, H. Psychological stress-induced enhancement of brain lipid peroxidation via nitric oxide systems and its modulation by anxiolytic and anxiogenic drugs in mice. Brain Res., 839(1):74-84, 1999.

Minaii, B.; Moayeri, A.; Shokri, S.; Roudkenar, M. H.; Golmohammadi, T.; Malek, F. \& Barbarestani, M. Melatonin improve the sperm quality in forced swimming test induced oxidative stress in nandrolone treated Wistar rats. Acta. Med. Iran., 52(7):496-504, 2014.

Mitra, S.; Srivastava, A. \& Khandelwal, S. Tributyltin chloride induced testicular toxicity by JNK and p38 activation, redox imbalance and cell death in sertoli-germ cell co-culture. Toxicology, 314(1):39-50, 2013.

Nargund, V. H. Effects of psychological stress on male fertility. Nat. Rev. Urol., 12(7):373-82, 2015.

Nishimuro, H.; Ohnishi, H.; Sato, M.; Ohnishi-Kameyama, M.; Matsunaga, I.; Naito, S.; Ippoushi, K.; Oike, H.; Nagata, T.; Akasaka, H.; et al. Estimated daily intake and seasonal food sources of quercetin in Japan. Nutrients, 7(4):2345-58, 2015.

Nordkap, L.; Jensen, T. K.; Hansen, Å. M.; Lassen, T. H.; Bang, A. K.; Joensen, U. N.; Jensen, M. B.; Skakkebæk, N. E. \& Jørgensen, N. Psychological stress and testicular function: a cross-sectional study of 1,215 Danish men. Fertil. Steril., 105(1):174-87.e1-2, 2016.

Othman, A. I.; Edrees, G. M.; El-Missiry, M. A.; Ali, D. A.; Aboel-Nour, M. \& Dabdoub, B. R. Melatonin controlled apoptosis and protected the testes and sperm quality against bisphenol A-induced oxidative toxicity. Toxicol. Ind. Health, 32(9):1537-49, 2016.

Pike, J. L.; Smith, T. L.; Hauger, R. L.; Nicassio, P. M.; Patterson, T. L.; McClintick, J.; Costlow, C. \& Irwin, M. R. Chronic life stress alters sympathetic, neuroendocrine, and immune responsivity to an acute psychological stressor in humans. Psychosom. Med., 59(4):447-57, 1997.

Prasad, S. V.; Ghongane, B. B.; Nayak, B. B.; Raul, A. R.; Kumar, A. N.;
Vijay; Mutalik, M. M. \& Kapuri, N. L. An experimental study on effect of antioxidant vitamin $\mathrm{E}$ in stress and alcohol induced changes in male fertility in albino rats. Int. J. Med. Res. Health Sci., 1(1):1-6, 2012.

Ren, L.; Li, X.; Weng, Q.; Trisomboon, H.; Yamamoto, T.; Pan, L.; Watanabe, G. \& Taya, K. Effects of acute restraint stress on sperm motility and secretion of pituitary, adrenocortical and gonadal hormones in adult male rats. J. Vet. Med. Sci., 72(11):1501-6, 2010.

Ribeiro, C. T.; De Souza, D. B.; Costa, W. S.; Sampaio, F. J. B. \& PereiraSampaio, M. A. Immediate and late effects of chronic stress in the testes of prepubertal and adult rats. Asian J. Androl., 20(4):385-90, 2018.

Samad, N.; Saleem, A.; Yasmin, F. \& Shehzad, M. A. Quercetin protects against stress-induced anxiety- and depression-like behavior and improves memory in male mice. Physiol. Res., 67(5):795-808, 2018.

Xu, D.; Hu, M. J.; Wang, Y. Q. \& Cui, Y. L. Antioxidant activities of quercetin and its complexes for medicinal application. Molecules, 24(6):1123, 2019.

Yang, H.; Song, Y.; Liang, Y. N. \& Li, R. Quercetin treatment improves renal function and protects the kidney in a rat model of adenine-induced chronic kidney disease. Med. Sci. Monit., 24:4760-6, 2018.

Zhang, J.; Sheng, Y.; Shi, L.; Zheng, Z.; Chen, M.; Lu, B. \& Ji, L. Quercetin and baicalein suppress monocrotaline-induced hepatic sinusoidal obstruction syndrome in rats. Eur. J. Pharmacol., 795:160-8, 2017.

Zhao, Y.; Tan, Y.; Dai, J.; Li, B.; Guo, L.; Cui, J.; Wang, G.; Shi, X.; Zhang, $\mathrm{X}$.; Mellen, N.; et al. Exacerbation of diabetes-induced testicular apoptosis by zinc deficiency is most likely associated with oxidative stress, p38 MAPK activation, and p53 activation in mice. Toxicol. Lett., 200(1-2):100-6, 2011.

\section{Corresponding author: \\ Professor Ismaeel Bin-Jaliah \\ Department of Physiology \\ College of Medicine \\ King Khalid University \\ P.O.Box 641 \\ Abha \\ 61421 Aseer \\ SAUDI ARABIA}

E-mail: isbinjaliah@kku.edu.sa

ORCID: Ismaeel Bin-Jaliah: 0000-0002-3029-2580

Received: 24-02-2021

Accepted: 04-04-2021 